\title{
Characterization of Aldosterone-induced Potassium Secretion in Rat Distal Colon
}

\author{
Jacob H. Sweiry and Henry J. Binder
}

Department of Internal Medicine, Yale University, New Haven, Connecticut 06510

\begin{abstract}
The role of apical and basolateral membranes in aldosteroneinduced active potassium $(K)$ secretion in rat distal colon was investigated by measuring mucosal-to-serosal $\left(J_{\mathrm{ms}}\right)$ and serosal-to-mucosal $\left(J_{\mathrm{sm}}\right)^{42} \mathrm{~K}$ fluxes $\left(\mu \mathrm{eq} \cdot \mathrm{h}^{-1} \cdot \mathrm{cm}^{-2}\right)$ across isolated stripped mucosa under short-circuit conditions in normal and secondary-hyperaldosterone animals. In normal colons mucosal tetraethylammonium (TEA; $30 \mathrm{mM}$ ) or barium (Ba; 5 $\mathrm{mM}$ ), but not cesium (Cs; $15 \mathrm{mM})$, reduced $J_{\mathrm{sm}}$ without affecting $J_{\mathrm{ms}}$. In aldosterone animals (a) net $K$ secretion $(-0.54 \pm 0.11)$ was converted to net $K$ absorption $(0.63 \pm 0.15)$ by mucosal TEA, which produced a marked reduction in $J_{\mathbf{s m}}$ $(0.82 \pm 0.07)$ and an increase in $J_{\mathrm{ms}}(0.35 \pm 0.07)$. In contrast mucosal Ba resulted in a relatively smaller reduction in $J_{\mathbf{s m}}^{\mathbf{K}}$ without altering $J_{\mathrm{ms}}^{\mathrm{K}}$, whereas mucosal Cs was ineffective; (b) serosal bumetanide or the removal of serosal $\mathrm{Na}$ or $\mathrm{Cl}$ markedly inhibited $J_{\mathrm{sm}}^{K}$ and abolished net $\mathrm{K}$ secretion; and (c) serosal ouabain (1 $\mathrm{mM}$ ) produced qualitatively similar effects to those of serosal bumetanide. These results demonstrate that $(a)$ normal rat distal colon contains apical TEA- and Ba-sensitive $K$ channels; (b) aldosterone induces TEA-sensitive and Ba-sensitive apical $\mathrm{K}$ channels; $(c)$ aldosterone-induced $\mathrm{K}$ secretion requires both the $\mathrm{Na}, \mathrm{K}$-pump and $\mathrm{Na}-\mathrm{K}-2 \mathrm{Cl}$ cotransport for $\mathrm{K}$ uptake across the basolateral membrane; and $(d)$ alteration of any of these processes results in inhibition of aldosterone-induced active $K$ secretion simultaneously with stimulation of $K$ absorption.
\end{abstract}

\section{Introduction}

Aldosterone stimulates active potassium $(\mathrm{K})$ secretion in the mammalian colon (1-3). Studies of aldosterone-induced active $\mathrm{K}$ secretion in the distal colon of the rat in vitro have demonstrated that this secretory process is $\mathrm{Na}$ dependent, $\mathrm{Cl}$ dependent, electrogenic, and amiloride insensitive (2), whereas electrophysiologic studies have suggested that aldosterone may induce a tetraethylammonium- (TEA) ${ }^{1}$ inhibitable $\mathrm{K}$ conductance in the apical membrane (4). The role of this apical channel in $K$ secretion has not been investigated, and it is not known whether this $\mathrm{K}$ channel is or can also be inhibited by other putative $\mathrm{K}$ channel blockers.

A portion of these studies has been published in abstract form (1988. J. Physiol. [Lond.]. 396:34P and 1988. FASEB (Fed. Am. Soc. Exp. Biol.) J. A748. [Abstr.]).

Received for publication 22 February 1988 and in revised form 21 October 1988.

1. Abbreviations used in this paper: $\mathrm{G}$, conductance; $I_{\mathrm{sc}}$, short-circuit current; $J_{\mathrm{ms}}^{\mathrm{K}}$, mucosal-to-serosal $\mathrm{K}$ flux; $J_{\text {net }}^{\mathrm{K}}$, net $\mathrm{K}$ movement; $J_{\mathrm{sm}}^{\mathrm{K}}$, serosal-to-mucosal $\mathrm{K}$ flux; PD, transmural potential difference; TEA, tetraethylammonium chloride.

J. Clin. Invest.

(c) The American Society for Clinical Investigation, Inc. 0021-9738/89/03/0844/08 $\$ 2.00$

Volume 83, March 1989, 844-851
The uptake of $\mathrm{K}$ across the basolateral membrane of colonic epithelial cells can be mediated by two distinct transport processes: $\mathrm{Na}, \mathrm{K}-\mathrm{ATPase}$ and $\mathrm{Na}-\mathrm{K}-2 \mathrm{Cl}$ cotransport. Hyperaldosteronism results in a significant increase in $\mathrm{Na}, \mathrm{K}-\mathrm{ATPase}$ activity (5) and the induction of electrogenic $\mathrm{Na}$ absorption (6). It is most likely therefore that the $\mathrm{Na}, \mathrm{K}$-pump is (at least partially) responsible for the increase in $\mathrm{K}$ uptake across the basolateral membrane in hyperaldosterone animals. However, $\mathrm{Na}-\mathrm{K}-2 \mathrm{Cl}$ cotransport process could also be involved in $\mathrm{K}$ secretion. This possibility is not unlikely because serosal bumetanide or furosemide, inhibitors of $\mathrm{Na}-\mathrm{K}-2 \mathrm{Cl}$ cotransport, block prostaglandin $E_{2}$, epinephrine, and adenosine-induced $K$ secretion in rabbit colon $(7,8)$ and vasoactive intestinal polypeptide-induced $\mathrm{Cl}$ secretion in $\mathrm{T}_{84}$ colonic cancer cells (9). Thus, it is not known whether the $\mathrm{Na}-\mathrm{K}-2 \mathrm{Cl}$ cotransport contributes to $\mathrm{K}$ uptake across the basolateral membrane in aldosterone-induced $\mathrm{K}$ secretion, and if so, the relative contribution of the $\mathrm{Na}, \mathrm{K}$-pump and $\mathrm{Na}-\mathrm{K}-2 \mathrm{Cl}$ cotransport to overall $\mathrm{K}$ secretion.

Schultz (see review, reference 10) has emphasized the importance of increased basolateral $\mathrm{K}$ conductance during situations in which there are enhanced rates of $\mathrm{Na}$ absorption and $\mathrm{Na}, \mathrm{K}$-pump activity. Thus, amino acid and sugar transport in the Necturus small intestine is associated with an increase in transepithelial $\mathrm{Na}$ absorption and basolateral $\mathrm{K}$ conductance (11); the addition of barium ( $\mathrm{Ba}$ ) to the serosal medium decreases both $\mathrm{K}$ conductance and $\mathrm{Na}$ absorption. Recently, studies by Dharmsathaphorn et al. (9) in $T_{84}$ colon cancer cells have indicated that Ba-sensitive basolateral $\mathrm{K}$ channels may be important in cAMP-stimulated $\mathrm{Cl}$ secretion. The role, if any, of basolateral $\mathrm{K}$ channels in the aldosterone-induced $\mathrm{K}$ secretion is unknown.

This study was designed to provide additional characterization of the mechanism of aldosterone-induced active $\mathrm{K}$ secretion in isolated distal colonic mucosa of Na-depleted rats. Attention was primarily directed towards identification of the properties of apical and basolateral $\mathrm{K}$ channels and the mechanism of $\mathrm{K}$ uptake across the basolateral membrane. The results demonstrate that aldosterone-induced $\mathbf{K}$ secretion is associated with the stimulation (or induction) of TEA-sensitive and Ba-sensitive $K$ channels in the apical membrane. Furthermore, these experiments establish a role for both $\mathrm{Na}, \mathrm{K}-\mathrm{ATP}$ ase and $\mathrm{Na}-\mathrm{K}-2 \mathrm{Cl}$ cotransport in aldosterone-induced $\mathrm{K}$ secretion by mediating the uptake of $K$ across the basolateral membrane of the distal colon.

\section{Methods}

Two groups of nonfasting male Sprague-Dawley rats weighing 220-280 g were used in this study. Group 1 rats were normal animals fed a standard diet (Prolab 3000; Agway Inc., Syracuse, NY) containing $19 \mathrm{meq} \mathrm{Na} / 100 \mathrm{~g}$ food and $24 \mathrm{meq} \mathrm{K} / 100 \mathrm{~g}$ food. Group 2 consisted of rats fed a paste diet (prepared in our laboratory) to which $\mathrm{Na}$ was not added and contained $20 \mathrm{meq} \mathrm{K} / 100 \mathrm{~g}$ food. The Na-deficient diet was given for a period of 7-9 d before the experiments to induce secondary hyperaldosteronism; previous studies have demonstrated that such animals have plasma aldosterone levels that are $\sim 100$-fold 
greater than normal animals (12). This group of rats will be referred to as the aldosterone or Na-depleted group.

The procedure has previously been described in detail (6). Approximately 15 min after mounting the last of eight segments, the transepithelial potential difference (PD) was noted, all tissues were then clamped to zero PD and the short-circuit current $\left(I_{\mathrm{sc}}\right)$ was measured, and the conductance (G) was calculated as previously described (6). The tissues were then paired on the basis of a conductance difference of $<10 \%$.

Transmural fluxes of potassium from mucosa-to-serosa or serosato-mucosa were measured under short-circuit conditions using ${ }^{42} \mathrm{~K}$ as previously described $(2,6)$. Under short-circuit conditions, net potassium transport $\left(J_{\text {net }}^{\mathrm{K}}\right)$ is active and defined as the difference between mucosal-to-serosal flux $\left(J_{\mathrm{ms}}^{\mathrm{K}}\right)$ and serosal-to-mucosal flux $\left(J_{\mathrm{sm}}^{\mathrm{K}}\right)$. Positive and negative values of $J_{\text {net }}^{\mathrm{K}}$ represent active absorption and active secretion, respectively.

The Ringer's solution contained (in millimolar per liter): $\mathrm{NaCl}$, $115, \mathrm{NaHCO}_{3}, 25 ; \mathrm{K}_{2} \mathrm{HPO}_{4}, 2.4 ; \mathrm{KH}_{2} \mathrm{PO}_{4}, 0.4 ; \mathrm{CaCl}_{2}, 1.2$ $\mathrm{MgCl}_{2} 6 \mathrm{H}_{2} \mathrm{O}, 1.2$; and glucose, 10 (pH 7.4). In sodium-free experiments, $\mathrm{NaCl}$ and $\mathrm{NaHCO}_{3}$ were replaced by equimolar choline-Cl and choline- $\mathrm{HCO}_{3}$, respectively. In chloride-free experiments, $\mathrm{NaCl}$ was replaced by equimolar $\mathrm{Na}$-isethionate, and $\mathrm{CaCl}_{2}$ and $\mathrm{MgCl}_{2}$ by their respective sulfate salt. In experiments in which the effect of barium was tested, $\mathrm{K}_{2} \mathrm{HPO}_{4}$ and $\mathrm{KH}_{2} \mathrm{PO}_{4}$ were replaced by equimolar $(5.2 \mathrm{mM})$ $\mathrm{KCl}$, to prevent precipitation of barium-phosphates. Drugs or other agents were added from concentrated stock solutions to give the desired concentration.

${ }^{42} \mathrm{~K}$ was purchased from New England Nuclear (Boston, MA). Bumetanide was a gift from Hoffmann-La Roche, Nutley, NJ. All other chemicals were purchased from Sigma Chemical Co., St. Louis, MO.

All values are expressed as mean \pm SEM. Statistical analysis was performed using paired (unless otherwise stated) $t$ test and a $P$ value of $\leq 0.05$ was considered significant.

\section{Results}

Table I demonstrates that net $\mathrm{K}$ absorption was present in normal animals and that secondary hyperaldosteronism converted this net $\mathrm{K}$ absorption to net $\mathrm{K}$ secretion. These results are in agreement with previous studies from our laboratory $(2,6)$.

Effect of ion substitution on $K$ secretion. The dependence of $\mathrm{K}$ secretion on serosal $\mathrm{Na}$ and/or $\mathrm{Cl}$ was investigated in $\mathrm{Na}$ depleted animals by completely substituting choline for $\mathrm{Na}$ and isethionate for $\mathrm{Cl}$ in the Ringer's solution bathing the serosal side. As shown in Table I (section B), the absence of serosal $\mathrm{Cl}$ resulted in the conversion of net $\mathrm{K}$ secretion to net $\mathrm{K}$ absorption as a result of a marked decrease in $J_{\mathrm{sm}}^{\mathrm{K}}$ and an increase in $J_{\mathrm{ms}}^{\mathrm{K}}$. The absence of serosal $\mathrm{Na}$ resulted in zero net $\mathrm{K}$ movement due to significant reduction $(41 \%)$ in $J_{\mathrm{sm}}^{\mathrm{K}}$ and increase $(50 \%)$ in $J_{\mathrm{ms}}^{\mathrm{K}}{ }^{2}$ In contrast, when mucosal and serosal

2. Because unidirectional $\mathrm{K}$ fluxes $\left(J_{\mathrm{ms}}^{\mathrm{K}}\right.$ and $\left.J_{\mathrm{sm}}^{\mathrm{K}}\right)$ represent the sum of active and passive components, results expressed in percentage terms refer to alterations in only the active component. Detailed analysis (Sweiry, J., and Binder, H. J., manuscript submitted for publication) demonstrated that in the absence of $\mathrm{Na}$ from mucosal and serosal solutions, $J_{\mathrm{sm}}^{\mathrm{K}}$ is a linear function of $\mathrm{K}$ concentration; at $\mathrm{K}=5.2 \mathrm{mM}$, $J_{\mathrm{sm}}^{\mathrm{K}}$ is 0.22 and $0.16 \mu \mathrm{eq} \cdot \mathrm{h}^{-1} \cdot \mathrm{cm}^{-2}$ in normal and Na-depleted animals, respectively. These values are not significantly different from those in the present study under similar conditions: $J_{\mathrm{sm}}^{\mathrm{K}}$ was $0.22 \pm 0.02$ and $0.19 \pm 0.03 \mu \mathrm{eq} \cdot \mathrm{h}^{-1} \cdot \mathrm{cm}^{-2}$ in normal $(n=9)$ and Na-depleted $(n$ $=8$ ) animals, respectively. Thus, the serosa-to-mucosa $\mathrm{K}$ flux measured in the absence of mucosal and serosal $\mathrm{Na}$ most likely represents diffusional movement of $K$. The active component of unidirectional $K$ movement is the difference between the isotopically determined unidirectional $\mathrm{K}$ movement and the diffusional component. sides were bathed by Na-free Ringer's, $J_{\mathrm{sm}}^{\mathrm{K}}$ was reduced to $0.19 \pm 0.03 \mu \mathrm{eq} \cdot \mathrm{h}^{-1} \cdot \mathrm{cm}^{-2}$, a value that probably reflects diffusional $\mathrm{K}$ movement, and $J_{\mathrm{ms}}^{\mathrm{K}}$ increased to $2.37 \pm 0.27(n=8)$, as shown previously (2).

Effect of serosal bumetanide and ouabain. The results obtained in the serosal side ion substitution experiments clearly demonstrate that serosal $\mathrm{Na}$ and $\mathrm{Cl}$ are required for maximal $\mathrm{K}$ secretion in aldosterone animals suggesting a role for $\mathbf{a}$ basolateral $\mathrm{Na}-\mathrm{K}-2 \mathrm{Cl}$ cotransport process and/or the $\mathrm{Na}, \mathrm{K}$ pump. We, therefore, tested the effect of serosal addition of bumetanide or ouabain, inhibitors of the former and latter transport systems, respectively.

In the normal distal colon $1 \mathrm{mM}$ bumetanide significantly inhibited the relatively low $J_{\mathrm{sm}}^{\mathrm{K}}(0.36 \pm 0.04$ vs. $0.23 \pm 0.02$ $\left.\mu \mathrm{eq} \cdot \mathrm{h}^{-1} \cdot \mathrm{cm}^{-2}, P<0.005\right)$. However, because of its small magnitude, the inhibitory effect was not reflected in a change in net $\mathrm{K}$ absorption. On the other hand in the Na-depleted animal $1 \mathrm{mM}$ bumetanide produced a marked inhibitory effect on $J_{\mathrm{sm}}^{\mathrm{K}}\left(1.40 \pm 0.05\right.$ vs. $0.43 \pm 0.03 \mu \mathrm{eq} \cdot \mathrm{h}^{-1} \cdot \mathrm{cm}^{-2}, P$ $<0.001)$ as well as a marked rise in $J_{\mathrm{ms}}^{\mathrm{K}}(0.80 \pm 0.09$ vs. $\left.1.27 \pm 0.16 \mu \mathrm{eq} \cdot \mathrm{h}^{-1} \cdot \mathrm{cm}^{-2}, P<0.005\right)$. Thus, net $\mathrm{K}$ secretion was converted to net $\mathrm{K}$ absorption $(0.83 \pm 0.16$ $\mu \mathrm{eq} \cdot \mathrm{h}^{-1} \cdot \mathrm{cm}^{-2}$ ). To test the specificity of the bumetanide effect, experiments were also performed in the Na-depleted group with $10 \mu \mathrm{M}$ bumetanide (Fig. 1). The effect of the addition of $10 \mu \mathrm{M}$ bumetanide (Fig. 1) was virtually identical to that observed with $1 \mathrm{mM}$ bumetanide. ${ }^{3} 10 \mu \mathrm{M}$ bumetanide also increased the $I_{\mathrm{sc}}$ by $1.1 \pm 0.3 \mu \mathrm{eq} \cdot \mathrm{h}^{-1} \cdot \mathrm{cm}^{-2}(P<0.01)$.

Fig. 2 illustrates the results obtained with serosal addition of $1 \mathrm{mM}$ ouabain (a large dose was used because of the known low sensitivity of rat tissues to glycosides) to the distal colon of $\mathrm{Na}$-depleted animals. Ouabain converted net $\mathrm{K}$ secretion $\left(-0.40 \pm 0.11 \mu \mathrm{eq} \cdot \mathrm{h}^{-1} \cdot \mathrm{cm}^{-2}\right)$ to a large net absorptive flux $\left(1.36 \pm 0.10 \mu \mathrm{eq} \cdot \mathrm{h}^{-1} \cdot \mathrm{cm}^{-2}\right)$ as a result of a marked inhibition $(\sim 88 \%)$ and augmentation $(\sim 120 \%)$ in the active components of $J_{\mathrm{sm}}^{\mathrm{K}}$ and $J_{\mathrm{ms}}^{\mathrm{K}}$, respectively. This was also accompanied by a marked reduction in the $I_{\mathrm{sc}}$ from $6.2 \pm 0.4$ to $1.9 \pm 0.2$ $\mu \mathrm{eq} \cdot \mathrm{h}^{-1} \cdot \mathrm{cm}^{-2}(P<0.001)$.

The increase in $I_{\mathrm{sc}}\left(1.1 \pm 0.3 \mu \mathrm{eq} \cdot \mathrm{h}^{-1} \cdot \mathrm{cm}^{-2}\right)$ in response to bumetanide $(10 \mu \mathrm{M})$ is consistent with a decrease in electrogenic $\mathrm{K}$ secretion as this change was very similar to the change in $J_{\mathrm{sm}}^{\mathrm{K}}\left(-0.97+0.05 \mu \mathrm{eq} \cdot \mathrm{h}^{-1} \cdot \mathrm{cm}^{-2}\right)$. In contrast, although serosal ouabain decreased $J_{\mathrm{sm}}^{\mathrm{K}}$ by an equivalent amount $\left(-0.95 \pm 0.18 \mu \mathrm{eq} \cdot \mathrm{h}^{-1} \cdot \mathrm{cm}^{-2}\right)$, the $I_{\mathrm{sc}}$ was inhibited (by $4.3 \pm 0.4$ $\mu \mathrm{eq} \cdot \mathrm{h}^{-1} \cdot \mathrm{cm}^{-2}$ ) (Fig. 2); the latter effect reflected an inhibition of electrogenic $\mathrm{Na}$ absorption, which is present in aldosterone animals $(6,13){ }^{4}$

Effect of putative $K$ channel blockers. The effects of putative $\mathrm{K}$ channel blockers were first studied in the aldosterone group, because in these animals a large $\mathrm{K}$ secretory flux was present compared to normal animals (Table I). When a $\mathrm{K}$

3. In limited studies in which only $J_{\mathrm{sm}}^{\mathrm{K}}$ was determined in aldosterone animals $1 \mu \mathrm{M}$ bumetanide reduced $J_{\mathrm{sm}}^{\mathrm{K}}$ from $1.50 \pm 0.07$ to $0.92 \pm 0.04$ $\mu \mathrm{eq} \cdot \mathrm{h}^{-1} \cdot \mathrm{cm}^{-2} ; n=12$.

4. Previous studies (6) have demonstrated that in sodium-depleted animals the $I_{\mathrm{sc}}$ can be accounted for by net $\mathrm{Na}$ absorption $(7.3 \pm 0.5 \mathrm{vs}$. $6.9 \pm 0.7 \mu \mathrm{eq} \cdot \mathrm{h}^{-1} \cdot \mathrm{cm}^{-2}$, respectively). The addition of $10 \mu \mathrm{M}$ amiloride to the mucosal bathing solution reduced $J_{\text {net }}^{\mathrm{Na}}$ almost to zero and unmasked electrogenic $\mathrm{K}$ secretion whose magnitude was relatively small compared to net $\mathrm{Na}$ absorption (between 0.7 and 1.1 $\mu \mathrm{eq} \cdot \mathrm{h}^{-1} \cdot \mathrm{cm}^{-2}(2)$. 
Table I. Potassium Fluxes and Associated Electrical Parameters in the Distal Colon of Normal and Na-depleted Rats, and the Effect of Ion Substitution in the Latter Group

\begin{tabular}{|c|c|c|c|c|c|c|c|}
\hline & $J_{\mathrm{ms}}$ & $J_{\mathrm{sm}}$ & $J_{\text {pet }}$ & $I_{\boldsymbol{s c}}$ & PD & G & $n$ \\
\hline & \multicolumn{4}{|c|}{$\mu e q \cdot h^{-1} \cdot \mathrm{cm}^{-2}$} & $m V$ & $\mathrm{mS} \cdot \mathrm{cm}^{-2}$ & \\
\hline \multicolumn{8}{|l|}{ A. Normal } \\
\hline Ringer's & $0.78 \pm 0.07$ & $0.41 \pm 0.03$ & $0.38 \pm 0.05$ & $0.8 \pm 0.1$ & $3.8 \pm 0.5$ & $5.6 \pm 0.4$ & 4 \\
\hline \multicolumn{8}{|l|}{ B. Na-depleted } \\
\hline Ringer’s & $0.69 \pm 0.05$ & $1.38 \pm 0.03$ & $-0.69 \pm 0.08$ & $6.9 \pm 0.7$ & $18.9 \pm 2.6$ & $10.2 \pm 0.8$ & \\
\hline$P^{*}$ & NS & $<0.001$ & $<0.001$ & $<0.001$ & $<0.005$ & $<0.005$ & 5 \\
\hline Serosal Na-free & $0.94 \pm 0.08$ & $0.88 \pm 0.08$ & $0.06 \pm 0.12$ & $7.5 \pm 0.6$ & $25.4 \pm 1.4$ & $8.0 \pm 0.7$ & \\
\hline$P^{\ddagger}$ & $<0.05$ & $<0.001$ & $<0.001$ & NS & $<0.05$ & NS & 7 \\
\hline Serosal Cl-free & $1.23 \pm 0.09$ & $0.61 \pm 0.08$ & $0.62 \pm 0.07$ & $5.9 \pm 0.4$ & $26.4 \pm 4.0$ & $6.4 \pm 0.7$ & \\
\hline$P^{\ddagger}$ & $<0.001$ & $<0.001$ & $<0.001$ & NS & NS & $<0.01$ & 5 \\
\hline
\end{tabular}

Values are mean \pm SE of two 15 -min flux periods; $n$, number of tissue pairs. PD, potential difference (millivolts, serosa positive); G, conductance. $J_{\mathrm{ms}}^{\mathrm{K}}$, mucosal-to-serosal potassium flux; $J_{\mathrm{sm}}^{\mathrm{K}}$, serosal-to-mucosal potassium flux; $J_{\mathrm{net}}^{\mathrm{K}}$, net potassium transport (absorption and secretion are represented by positive and negative values, respectively); $I_{s c}$, short-circuit current. Unless otherwise stated solutions were normal Ringer's on both mucosal and serosal sides. Sodium and chloride were replaced by choline and isethionate, respectively. $P$ (unpaired $t$ tests) values are: * compared with normal group (A); ${ }^{\ddagger}$ compared with Na-depleted group in Ringer's.

channel blocker was found to alter $\mathrm{K}$ transport, the same experimental protocol was repeated in the colon of normal animals.

Table II shows the effects of mucosal addition of TEA (30 $\mathrm{mM}), 5 \mathrm{mM} \mathrm{Ba}$, or $15 \mathrm{mM} \mathrm{Cs}$ on unidirectional and net $\mathrm{K}$ fluxes across the distal colon of sodium-depleted rats. ${ }^{5}$ Mucosal TEA reversed net $\mathrm{K}$ secretion $\left(-0.54 \pm 0.10 \mu \mathrm{eq} \cdot \mathrm{h}^{-1} \cdot \mathrm{cm}^{-2}\right)$ observed in the aldosterone group to net $\mathrm{K}$ absorption $\left(0.63 \pm 0.15 \mu \mathrm{eq} \cdot \mathrm{h}^{-1} \cdot \mathrm{cm}^{-2}\right)$, as a result of both a marked decrease in $J_{\mathrm{sm}}^{\mathrm{K}}$ and an increase in $J_{\mathrm{ms}}^{\mathrm{K}}$. Mucosal Ba abolished net $\mathrm{K}$ secretion $\left(-0.67 \pm 0.11\right.$ vs. $\left.0.03 \pm 0.1 \mu \mathrm{eq} \cdot \mathrm{h}^{-1} \cdot \mathrm{cm}^{-2}\right)$ mainly as a result of a reduction in $J_{\mathrm{sm}}^{\mathrm{K}}$. Compared with TEA, the inhibition of $J_{\mathrm{sm}}^{\mathrm{K}}$ by Ba was smaller $(0.54 \pm 0.01$ vs. $0.82 \pm 0.07$ $\mu \mathrm{eq} \cdot \mathrm{h}^{-1} \cdot \mathrm{cm}^{-2}$, respectively, $\left.P<0.05\right)$. Mucosal Cs did not alter unidirectional $\mathrm{K}$ fluxes.

Table III shows the results obtained with serosal addition of TEA, $\mathrm{Ba}$, or Cs in the aldosterone group. Serosal TEA was ineffective in inhibiting either unidirectional $\mathrm{K}$ fluxes, and serosal $\mathrm{Ba}$ only marginally reduced $J_{\mathrm{ms}}^{\mathrm{K}}$ without a significant effect on any of the parameters measured. Serosal Cs, however, produced a marked effect on unidirectional and net $\mathrm{K}$ fluxes; $J_{\text {net }}^{\mathrm{K}}$ was reversed from net secretion to net absorption as a consequence of an $\sim 83 \%$ decrease in $J_{\mathrm{sm}}^{\mathrm{K}}$ and $\sim 144 \%$ increase in $J_{\mathrm{ms}}^{\mathrm{K}}$. In normal animals serosal Cs did not affect $J_{\mathrm{ms}}^{\mathrm{K}}$ : $0.74 \pm 0.10$ vs. $0.78 \pm 0.09 \mu \mathrm{eq} \cdot \mathrm{h}^{-1} \cdot \mathrm{cm}^{-2}$, but $J_{\mathrm{sm}}^{\mathrm{K}}$ was significantly reduced: $0.56 \pm 0.07$ vs. $0.27 \pm 0.02 \mu \mathrm{eq} \cdot \mathrm{h}^{-1} \cdot \mathrm{cm}^{-2}(P$ $<0.005)$. To distinguish whether the effect of Cs was due to an inhibition of a basolateral $\mathrm{K}$ channel or an effect on basolateral $\mathrm{Na}-\mathrm{K}-2 \mathrm{Cl}$ cotransport that exists in this tissue (see above), experiments were conducted in the absence of $\mathrm{Cl}$ from the serosal solution. Under these conditions the cotransport system would not be functional and any effect of serosal Cs would be due to either competition for $\mathrm{K}$ uptake via the $\mathrm{Na}, \mathrm{K}$-pump or an effect on basolateral $\mathrm{K}$ channel. The results (Table III

5. Preliminary studies demonstrated that in aldosterone animals the mucosal addition of both 30 and $40 \mathrm{mM}$ TEA and both 5 and $10 \mathrm{mM}$ Ba produced identical changes in $J_{\mathrm{sm}}^{\mathrm{K}}$ and that of $10 \mathrm{mM} \mathrm{Ba}$ and 30 $\mathrm{mM}$ Cs did not alter $J_{\mathrm{ms}}^{\mathrm{K}}$ or $J_{\mathrm{sm}}^{\mathrm{K}}$, respectively. [section D]) demonstrate that although $J_{\mathrm{sm}}^{\mathrm{K}}$ was significantly reduced, the absorption of $\mathrm{Na}$ (represented by the $I_{\text {sc }}$ ) was unaffected and therefore, the $\mathrm{Na}, \mathrm{K}$-pump was still operative. Thus, Cs affects active $\mathrm{K}$ secretion primarily by inhibiting $\mathrm{Na}-\mathrm{K}-2 \mathrm{Cl}$ cotransport system; the $\mathrm{Na}, \mathrm{K}-\mathrm{ATPase}$ appears to have an affinity for $\mathrm{Cs}$ resulting in a reduction in $\mathrm{K}$ uptake but without affecting pump activity.

The putative $\mathrm{K}$ channel blockers that were effective in blocking $\mathrm{K}$ fluxes across colonic mucosa of the aldosterone group, namely mucosal TEA or Ba, were further investigated to determine their effect on $\mathrm{K}$ transport in the colon of the normal rat (Fig. 3). TEA reduced the active component of $J_{\mathrm{sm}}^{\mathrm{K}}$ by $100 \%$ to a value $\left(0.21 \pm 0.02 \mu \mathrm{eq} \cdot \mathrm{h}^{-1} \cdot \mathrm{cm}^{-2}\right)$ representative of diffusional transfer ${ }^{2}$ but, because of a small reduction in $J_{\mathrm{ms}}^{\mathrm{K}}$ that is unlike that observed in the aldosterone group (Table

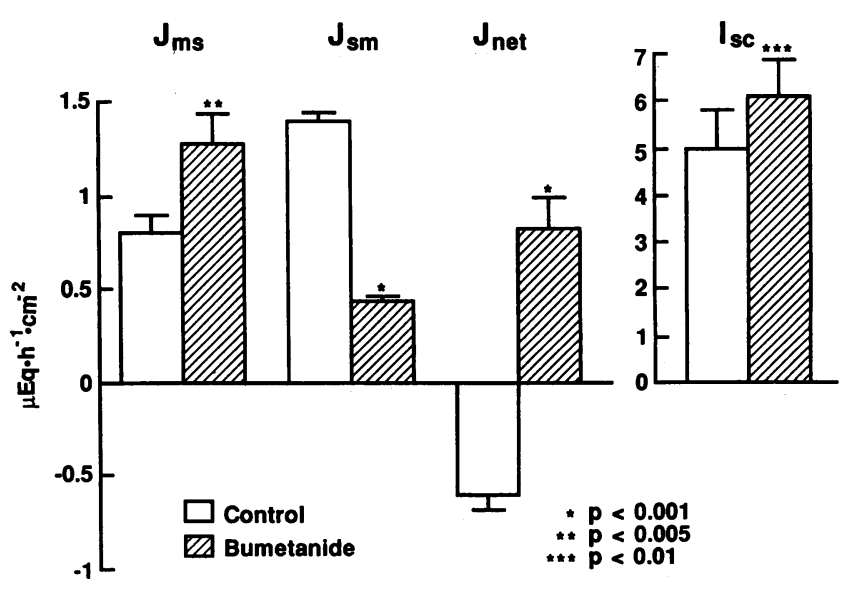

Figure 1. Effect of serosal bumetanide on unidirectional and net potassium fluxes, and short-circuit current in hyperaldosterone animals. Mucosal and serosal sides were bathed with normal Ringer's and bumetanide was added to give a final concentration of $10 \mu \mathrm{M}$. The control and post-bumetanide conductance were $8.2 \pm 0.4$ and $6.3 \pm 0.5 \mathrm{mS} \cdot \mathrm{cm}^{-2}(P<0.001)$, respectively. Results are from six tissue pairs. 


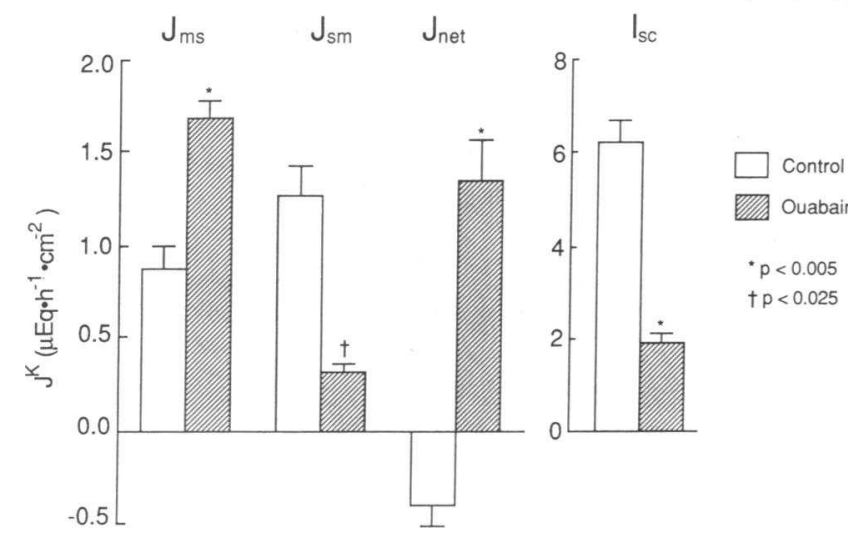

Figure 2. Effect of ouabain on unidirectional and net potassium fluxes and short-circuit current $\left(I_{\mathrm{sc}}\right)$ in the Na-depleted group. Both sides of the colonic mucosa were bathed with normal Ringer solution and $1 \mathrm{mM}$ ouabain was added to the serosal side. The conductances before and after ouabain were $\left(\mathrm{mS} \cdot \mathrm{cm}^{-2}\right): 10.3 \pm 1.32$ vs. $10.7 \pm 1.13$, $P=$ NS. Results (mean \pm SE) are from seven tissue pairs.

II), there was no significant change in $J_{\text {net }}^{\mathrm{K}}$. Mucosal Ba also reduced the active component of $J_{\mathrm{sm}}^{\mathrm{K}}$ by $100 \%$ without an apparent effect on $J_{\mathrm{ms}}^{\mathrm{K}}$. Thus both TEA and Ba totally abolished the active component of $J_{\mathrm{sm}}^{\mathrm{K}}$ in normal animals. In contrast, in the aldosterone group the inhibition of $J_{\mathrm{sm}}^{\mathrm{K}}$ by TEA was significantly greater than that by $\mathrm{Ba}$ ( 80 and $42 \%$, respectively). Thus, the TEA-insensitive component of $J_{\mathrm{sm}}^{\mathrm{K}}$ was significantly smaller than the Ba-insensitive component $\left(0.39 \pm 0.06\right.$ and $0.92 \pm 0.12 \mu \mathrm{eq} \cdot \mathrm{h}^{-1} \cdot \mathrm{cm}^{-2}$, respectively; $P$ $<0.005)$. This analysis suggests that in normal animals the apical $\mathrm{K}$ channel is both TEA- and Ba-sensitive, but that aldosterone induces (or activates) a new population of $\mathrm{K}$ channels which exhibit a greater sensitivity to TEA than to $\mathrm{Ba}$.

Relationship between $\mathrm{Na}$ absorption and $\mathrm{K}$ secretion. A relationship between $\mathrm{Na}$ absorption and $\mathrm{K}$ secretion has frequently been suggested. However, previous studies in the distal colon of hyperaldosterone animals have demonstrated that amiloride has no effect on $\mathrm{K}$ secretion even though electrogenic $\mathrm{Na}$ absorption is inhibited $(2,13)$. It is possible therefore, that $\mathrm{K}$ secretion could be sustained by serosal $\mathrm{Na}$ uptake alone when apical $\mathrm{Na}$ entry is inhibited. In this study when $\mathrm{Na}$ was absent from the serosal solution (but present in the mucosal solution), the active component of $J_{\mathrm{sm}}^{\mathrm{K}}$ was reduced by $\sim 42 \%$ with no apparent change in $\mathrm{Na}$ absorption as indicated by the $I_{\mathrm{sc}}$ (Table I). Under these conditions the addition of mucosal amiloride $(10 \mu \mathrm{M})$ resulted in a further substantial decrease in $J_{\mathrm{sm}}^{\mathrm{K}}$ simultaneous with a further rise in $J_{\mathrm{ms}}^{\mathrm{K}}$, resulted in a large net absorption of $\mathrm{K}$ (Fig. 4). At the same time the $I_{\mathrm{sc}}$, which reflects electrogenic $\mathrm{Na}$ absorption $(2,13)$, was reduced from $7.6 \pm 0.6$ to $1.8 \pm 0.1 \mu \mathrm{eq} \cdot \mathrm{h}^{-1} \cdot \mathrm{cm}^{-2}, P<0.001$. These results suggest that under certain conditions (i.e., when $\mathrm{K}$ and $\mathrm{Na}$ uptake via the basolateral $\mathrm{Na}-\mathrm{K}-2 \mathrm{Cl}$ cotransport system is inhibited) part of the $\mathrm{K}$ secretory flux appears linked to $\mathrm{Na}$ absorption.

\section{Discussion}

The movement of $\mathrm{K}$ in the rat distal colon is the result of both active and passive transport processes and both absorptive and secretory processes. In vivo there is net secretion that in large part represents potential dependent $\mathrm{K}$ movement (1). In contrast, under short circuit conditions net $\mathrm{K}$ absorption is observed that appears to be electroneutral, $\mathrm{Na}$ dependent, probably $\mathrm{Cl}$ dependent, and consistent with a $\mathrm{K}-\mathrm{H}$ exchange (2). Active $\mathrm{K}$ transport can regulate net $\mathrm{K}$ movement in that $\mathrm{K}$ depletion augments active $\mathrm{K}$ absorption while aldosterone and $\mathrm{K}$ loading induce active $\mathrm{K}$ secretion $(2,14)$.

This study was designed to characterize aldosterone-induced electrogenic $\mathrm{K}$ secretion in rat distal colon and has demonstrated that this transport process requires $(a)$ both serosal $\mathrm{Na}$ and serosal $\mathrm{Cl} ;(b)$ both the $\mathrm{Na}, \mathrm{K}$-pump and $\mathrm{Na}-\mathrm{K}-2 \mathrm{Cl}$ cotransport for $\mathrm{K}$ uptake across the basolateral membrane; and $(c)$ an aldosterone-induced apical TEA-sensitive, Ba-sensitive $\mathrm{K}$ channel for $\mathrm{K}$ exit across the apical membrane. A basolateral $\mathrm{K}$ channel appears to be absent based on sensitivity to the putative $\mathrm{K}$ channel blockers TEA, $\mathrm{Ba}$, and $\mathrm{Cs}$. In the normal colon the small active component of $J_{\mathrm{sm}}^{\mathrm{K}}$ could be completely accounted for by an apical TEA- or Ba-sensitive $\mathrm{K}$ channel and a basolateral $\mathrm{Na}-\mathrm{K}-2 \mathrm{Cl}$ cotransport process.

Table II. Effect of Mucosal TEA, Ba, or Cs on Unidirectional and Net Potassium Fluxes, and on Electrical Parameters in the Distal Colonic Mucosa of the Aldosterone Group

\begin{tabular}{|c|c|c|c|c|c|c|c|}
\hline & $J_{\mathrm{ms}}$ & $J_{\mathrm{sm}}$ & $J_{\text {net }}$ & $I_{\mathbf{s c}}$ & PD & G & $n$ \\
\hline & \multicolumn{4}{|c|}{$\mu e q \cdot h^{-1} \cdot \mathrm{cm}^{-2}$} & $m V$ & $\mathrm{mS} \cdot \mathrm{cm}^{-2}$ & \\
\hline A. Ringer's & $0.67 \pm 0.07$ & $1.21 \pm 0.05$ & $-0.54 \pm 0.11$ & $3.5 \pm 0.6$ & $9.3 \pm 2.2$ & $10.9 \pm 1.1$ & 7 \\
\hline +TEA & $1.03 \pm 0.11$ & $0.39 \pm 0.06$ & $0.63 \pm 0.15$ & $4.2 \pm 0.4$ & $9.7 \pm 1.9$ & $13.0 \pm 1.6$ & \\
\hline$P$ & $<0.005$ & $<0.001$ & $<0.001$ & $<0.025$ & NS & $<0.01$ & \\
\hline B. Ringer's & $0.79 \pm 0.14$ & $1.46 \pm 0.05$ & $-0.67 \pm 0.11$ & $5.7 \pm 0.4$ & $18.2 \pm 2.3$ & $8.9 \pm 0.9$ & 6 \\
\hline$+\mathrm{Ba}$ & $0.95 \pm 0.14$ & $0.92 \pm 0.12$ & $0.03 \pm 0.10$ & $5.7 \pm 0.3$ & $18.6 \pm 2.1$ & $8.6 \pm 0.9$ & \\
\hline$P$ & NS & $<0.005$ & $<0.01$ & NS & NS & NS & \\
\hline C. Ringer's & $1.08 \pm 0.10$ & $1.81 \pm 0.13$ & $-0.73 \pm 0.20$ & $4.9 \pm 0.4$ & $11.6 \pm 1.6$ & $13.2 \pm 2.4$ & 4 \\
\hline$+\mathrm{Cs}$ & $1.03 \pm 0.16$ & $1.83 \pm 0.15$ & $-0.81 \pm 0.31$ & $3.9 \pm 0.2$ & $8.7 \pm 1.7$ & $13.8 \pm 2.2$ & \\
\hline$P$ & NS & NS & NS & NS & $<0.02$ & NS & \\
\hline
\end{tabular}

$P$ (paired $t$ test) compares the difference between control and experimental values. When agents were added to mucosal or serosal Ringer's, equimolar choline-chloride was added to the opposite compartment. See legend to Table I for definitions and additional information. 
Table III. Effects of Serosal TEA, Ba, or Cs on Unidirectional and Net Potassium Fluxes, and on Electrical Parameters in Distal Colonic Mucosa of the Aldosterone Group

\begin{tabular}{|c|c|c|c|c|c|c|c|}
\hline & $J_{\mathrm{ms}}$ & $J_{\mathrm{sm}}$ & $J_{\text {net }}$ & $I_{\mathbf{s c}}$ & PD & G & $n$ \\
\hline & \multicolumn{4}{|c|}{$\mu e q \cdot h^{-1} \cdot \mathrm{cm}^{-2}$} & $m V$ & $\mathrm{mS} \cdot \mathrm{cm}^{-2}$ & \\
\hline A. Ringer's & $0.69 \pm 0.05$ & $1.38 \pm 0.03$ & $-0.69 \pm 0.08$ & $6.9 \pm 0.7$ & $18.9 \pm 2.6$ & $10.2 \pm 0.8$ & 5 \\
\hline +TEA & $0.60 \pm 0.05$ & $1.33 \pm 0.09$ & $-0.73 \pm 0.13$ & $7.5 \pm 0.6$ & $18.1 \pm 2.0$ & $11.6 \pm 1.0$ & \\
\hline$P$ & NS & NS & NS & NS & NS & NS & \\
\hline B. Ringer's & $0.78 \pm 0.08$ & $1.27 \pm 0.14$ & $-0.50 \pm 0.14$ & $5.9 \pm 1.0$ & $15.7 \pm 2.4$ & $10.1 \pm 1.1$ & 5 \\
\hline$+\mathrm{Ba}$ & $0.64 \pm 0.05$ & $1.15 \pm 0.12$ & $-0.50 \pm 0.13$ & $7.6 \pm 1.1$ & $20.2 \pm 2.6$ & $10.9 \pm 1.8$ & \\
\hline$P$ & $<0.05$ & NS & NS & NS & NS & NS & \\
\hline C. Ringer's & $0.60 \pm 0.06$ & $1.54 \pm 0.14$ & $-0.94 \pm 0.09$ & $5.3 \pm 0.8$ & $14.1 \pm 2.6$ & $10.3 \pm 0.9$ & 5 \\
\hline$+\mathrm{Cs}$ & $1.19 \pm 0.04$ & $0.42 \pm 0.04$ & $0.77 \pm 0.04$ & $8.0 \pm 1.0$ & $22.6 \pm 3.7$ & $10.3 \pm 1.8$ & \\
\hline$P$ & $<0.001$ & $<0.005$ & $<0.001$ & NS & $<0.005$ & NS & \\
\hline D. Serosal Cl-free & $1.13 \pm 0.10$ & $0.61 \pm 0.01$ & $0.51 \pm 0.10$ & $5.9 \pm 0.4$ & $31.9 \pm 4.3$ & $5.3 \pm 0.7$ & 5 \\
\hline$+\mathrm{Cs}$ & $1.43 \pm 0.12$ & $0.42 \pm 0.04$ & $1.01 \pm 0.14$ & $5.9 \pm 0.4$ & $25.4 \pm 3.3$ & $6.8 \pm 0.9$ & \\
\hline$P$ & $<0.001$ & $<0.005$ & $<0.001$ & NS & $<0.02$ & $<0.01$ & \\
\hline
\end{tabular}

$P$ (paired $t$ test) compares the difference between control and experimental values. See legend to Table I for definitions and additional information.

Role of basolateral $\mathrm{Na}-\mathrm{K}-2 \mathrm{Cl}$ cotransport and $\mathrm{Na}, \mathrm{K}$-pump in $K$ secretion. A $\mathrm{Na}-\mathrm{K}-2 \mathrm{Cl}$ cotransport process exists in a variety of cell types and plays a central role in electrolyte and fluid transport in epithelial tissues (see review, reference 15). Two features of this cotransport systems are its specific inhibition by low dose (micromolar range) of the loop diuretic bumetanide and interdependency of ion fluxes. In this study $\mathrm{K}$ secretion $\left(J_{\mathrm{sm}}^{\mathrm{K}}\right)$ was dependent on both serosal $\mathrm{Na}$ and $\mathrm{Cl}$ (Table I) and was inhibited by serosal bumetanide (Fig. 1). These experiments, therefore, indicate the existence of a $\mathrm{Na}-\mathrm{K}-2 \mathrm{Cl}$ cotransport process on the basolateral membrane of the rat distal colon. ${ }^{6}$ Moreover, it appears that a major portion of active $\mathrm{K}$ secretion is driven by this cotransport process since in the presence of $10 \mu \mathrm{M}$ bumetanide, ${ }^{3}$ or in the absence of serosal $\mathrm{Cl}, J_{\mathrm{sm}}^{\mathrm{K}}$ was reduced by 83 and $65 \%$, respectively, in aldosterone animals. (In normal animals bumetanide reduced the small $J_{\mathrm{sm}}^{\mathrm{K}}$ to a value equivalent to passive transfer.) In a similar study in rabbit descending colon, both basal and adenosine-stimulated $J_{\mathrm{sm}}^{\mathrm{K}}$ were abolished in the absence of serosal $\mathrm{Cl}$ or $\mathrm{Na}$, or with serosal furosemide, indicating that only $\mathrm{K}$ which enters via the basolateral $\mathrm{Na}-\mathrm{K}-2 \mathrm{Cl}$ cotransport is available for $\mathrm{K}$ secretion (8).

Chronic dietary Na-depletion results in a marked increase in $\mathrm{Na}, \mathrm{K}-\mathrm{ATPase}$ activity due to an increase in pump density in basolateral membrane (5). The increase in $\mathrm{K}$ secretion during hyperaldosteronism could therefore be attributed to the increase in the Na,K-ATPase activity in the basolateral membrane (in addition to an increase in apical $\mathrm{K}$ conductance discussed below). Thus, serosal ouabain inhibited $J_{\mathrm{sm}}^{\mathrm{K}}$ by $\sim 90 \%$ (Fig. 2), to a value similar to that obtained with serosal

6. Although bumetanide inhibits $\mathrm{Na}-\mathrm{K}-2 \mathrm{Cl}$ cotransport as well as $\mathrm{KCl}$ cotransport and anion exchange, the $\mathrm{IC}_{0.5}$ of bumetanide for $\mathrm{Na}-\mathrm{K}-2 \mathrm{Cl}$ cotransport is $<1 \mu \mathrm{M}$ in flounder intestine (36) and rabbit thick ascending limb of Henle (37). The comparable inhibition (approximately $75 \%$ ) by $1 \mathrm{mM}$ and $10 \mu \mathrm{M}$ bumetanide and the $45 \%$ inhibition of the active component of $J_{\mathrm{sm}}^{\mathrm{K}}$ by $1 \mu \mathrm{M}$ bumetanide indicates that the $\mathrm{IC}_{0.5}$ of bumetanide for $\mathrm{K}$ secretion is $\sim 1 \mu \mathrm{M}$ and provides compelling evidence for the presence of $\mathrm{Na}-\mathrm{K}-2 \mathrm{Cl}$ cotransport in the rat distal colon. bumetanide (Fig. 1), suggesting a relationship between the $\mathrm{Na}, \mathrm{K}$-pump and $\mathrm{Na}-\mathrm{K}-2 \mathrm{Cl}$ cotransport such that both transport systems are required for $\mathrm{K}$ secretion. It is likely that the $\mathrm{Na}, \mathrm{K}$-pump maintains the transmembrane Na-gradient, which is necessary for normal operation of the cotransport process. Unlike bumetanide, however, ouabain produced a large decline in the $I_{\mathrm{sc}}$, indicating inhibition of electrogenic $\mathrm{Na}$ absorption. ${ }^{4}$ This effect has also been observed in rabbit descending colon where ouabain decreased the $I_{\mathrm{sc}}$ and transepithelial PD to near zero levels and reduced $J_{\mathrm{sm}}^{\mathrm{K}}$ by $65-100 \%(7$,

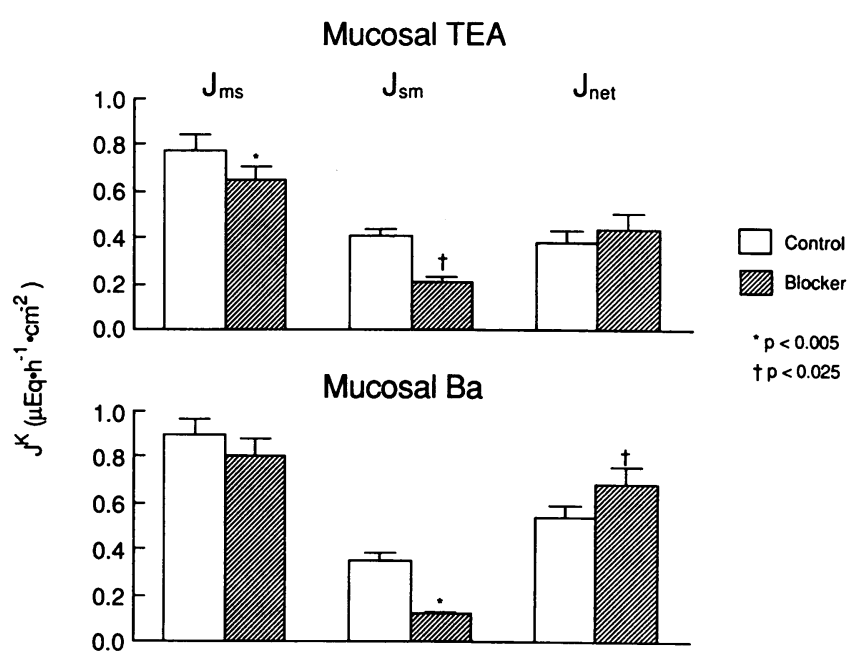

Figure 3. Comparison of the effect of putative $\mathrm{K}$ channel blockers on unidirectional and net potassium fluxes across the distal colon of normal animals. The control vs. post blocker $I_{\mathrm{sc}}\left(\mu \mathrm{eq} \cdot \mathrm{h}^{-1} \cdot \mathrm{cm}^{-2}\right)$ were: mucosal TEA, $0.81 \pm 0.13$ vs. $1.85 \pm 0.14, P<0.001$; mucosal $\mathrm{Ba}, 0.51 \pm 0.08$ vs. $0.80 \pm 0.05, P<0.005$. Similarly the conductances $\left(\mathrm{mS} \cdot \mathrm{cm}^{-2}\right.$ ) were: $5.6 \pm 0.4$ vs. $7.5, P<0.001$ and $4.8 \pm 0.4$ vs.

$4.5 \pm 0.4, P=\mathrm{NS}$, respectively. Results represent the mean of two $15-$ min flux periods before and after the addition of $30 \mathrm{mM} \mathrm{TEACl}$ or 5 $\mathrm{mM} \mathrm{BaSO}_{4}$ to the mucosal bathing solution (and 30 or $5 \mathrm{mM}$ choline- $\mathrm{Cl}$ to the serosal bathing solution, respectively). Results are mean $\pm S E$ from four tissue pairs in each group. 

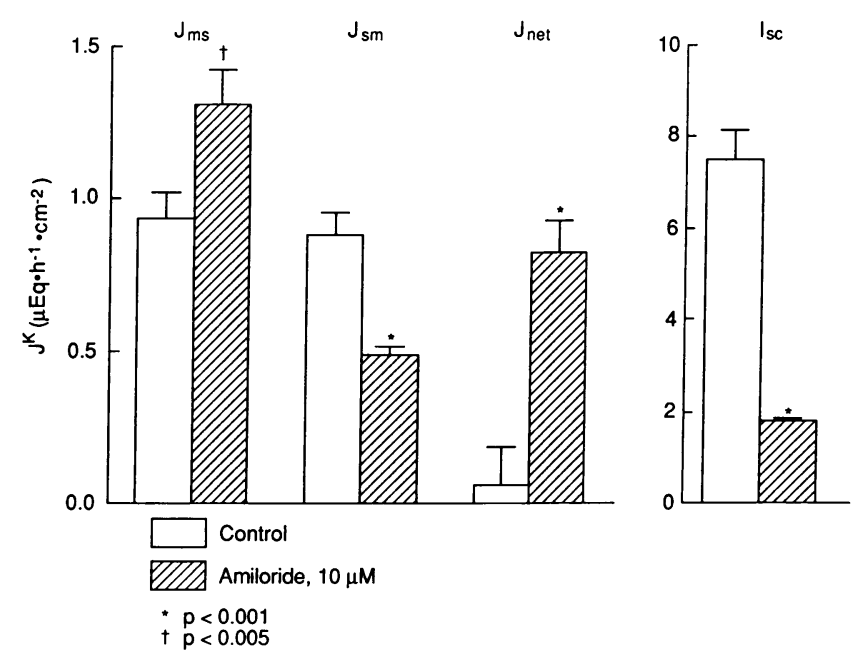

Figure 4. Effect of mucosal amiloride on unidirectional and net potassium fluxes and short-circuit current $\left(I_{\mathrm{sc}}\right)$ across distal colonic mucosa of dietary Na-depleted animals. The mucosal and serosal sides were bathed with normal and $\mathrm{Na}$-free (choline substituted) Ringer's, respectively. $10 \mu \mathrm{M}$ amiloride was added. Results are from seven tissue pairs.

16). Neither bumetanide nor removal of $\mathrm{Cl}$ from the serosal bathing solution reduced $I_{\mathrm{sc}}$ (and thus did not affect the $\mathrm{Na}, \mathrm{K}$ pump) but markedly inhibited $J_{\mathrm{sm}}^{\mathrm{K}}$ (Fig. 1 and Table I [section B]) suggesting that a major source of $\mathrm{K}$ for secretion is that which enters the cell via the $\mathrm{Na}-\mathrm{K}-2 \mathrm{Cl}$ cotransport process.

Role of apical and basolateral K channels. Numerous electrophysiological studies have established that $\mathrm{K}$ channels, exhibiting variable sensitivity to certain cations, exist in the apical and basolateral membranes of various types of epithelia and that a major function of these channels appears to be the regulation of transepithelial $\mathrm{K}$ movement (see review, reference 17). Studies in rabbit cortical collecting duct and distal colon demonstrate an apical membrane conductive pathway for $\mathrm{K}$ exit which is blocked by either TEA or $\mathrm{Ba}(7,8,16$, 18-20). In the rat distal colon, conventional microelectrode studies in our laboratory have indicated that a TEA-inhibitable $K$ conductance is present on the mucosal side during chronic dietary potassium loading (4). By using these putative $\mathrm{K}$ channel blockers the present study provides evidence to suggest that $K$ exit across the apical membrane occurs via $K$ channels since in the aldosterone rat mucosal TEA or $\mathrm{Ba}$, but not Cs, prevented net $\mathrm{K}$ secretion (Table II). Although both mucosal TEA and Ba completely inhibited active $J_{\mathrm{sm}}^{\mathrm{K}}$ in normal animals (Fig. 3), their effect in the aldosterone group was strikingly different. ${ }^{5}$ TEA in Na-depleted animals resulted a substantial $(80 \%)$ reduction in the active component of $J_{\mathrm{sm}}^{\mathrm{K}}$, but $\mathrm{Ba}$ reduced this component by only $42 \%$. These data can best be interpreted to indicate that aldosterone induces (or activates) a new population of $K$ channels which exhibit a higher sensitivity to TEA than to $\mathrm{Ba}$, whereas in normal animals the apical $\mathrm{K}$ channel is TEA and Ba sensitive. Similar findings were recently reported (21) in the guinea-pig distal colon where application of TEA or $\mathrm{Ba}$ to the mucosal side caused a reversible increase in $I_{\mathrm{sc}}$ (an indicator of electrogenic K secretion).

Basolateral $\mathrm{K}$ conductance, which is largely $\mathrm{Ba}$ inhibitable, is present in a variety of epithelia $(17,18,21,22,23)$. In this study serosal TEA or Ba had no significant effect on $\mathrm{K}$ fluxes in either direction across the distal colon (Table III) indicating the absence of a basolateral TEA- or Ba-sensitive $\mathrm{K}$ channels. Note, however, that Gregor has recently suggested that $K$ movement across the basolateral membrane of some epithelial cells (e.g. rabbit cortical thick ascending limb of Henle, Necturus gallbladder) occurs via a $\mathrm{KCl}$ cotransport process (24).

Although serosal Cs markedly decreased $\mathrm{K}$ secretiōn, this effect is not primarily a direct effect of Cs on a basolateral $\mathrm{K}$ channel for the following reasons: first, in the absence of serosal $\mathrm{Cl}$ when $\mathrm{Na}-\mathrm{K}-2 \mathrm{Cl}$ cotransport is inhibited, the effect of $\mathrm{Cs}$ on $J_{\mathrm{sm}}^{\mathrm{K}}$ was small (and may be due to interaction with the $\mathrm{Na}, \mathrm{K}$-pump; see reference 25) compared with that in normal Ringer's (Table III [section C and D]). Second, if Cs blocks a basolateral $\mathrm{K}$ channel, then its addition to the serosal side should reduce the activity of the $\mathrm{Na}, \mathrm{K}$-pump by virtue of decreasing $\mathrm{K}$ cycling, which should result in a reduction in electrogenic $\mathrm{Na}$ absorption in the aldosterone animal. Such effects have been observed in Necturus urinary bladder, where addition of serosal $\mathrm{Ba}$ reduced basolateral $\mathrm{K}$ conductance and blocked apical $\mathrm{Na}$ channels as reflected in the increase in basolateral and apical membrane resistance, respectively (26). Our results demonstrate that the elevated $I_{\mathrm{sc}}$, an indicator of electrogenic $\mathrm{Na}$ absorption, was not reduced in the presence of serosal Cs (Table III [section C]). Together, these findings argue against a Cs-sensitive basolateral $\mathrm{K}$ channel and indicate that $\mathrm{Cs}$ inhibits $\mathrm{Na}-\mathrm{K}-2 \mathrm{Cl}$ cotransport. Of interest is evidence in rectal gland plasma membrane vesicles that $\mathrm{Cs}$ interacts with the Na-K-2Cl symporter without being transported (27).

Relationship of $\mathrm{K}$ secretion to Na absorption. Traditionally the Koefoed-Johnsen and Ussing model for active Na absorption implies that $\mathrm{K}$ uptake across the basolateral membrane is linked to the simultaneous absorption of $\mathrm{Na}$, as would be expected from the coupling between $\mathrm{Na}$ efflux and $\mathrm{K}$ influx, and mediated by the basolateral membrane $\mathrm{Na}, \mathrm{K}-\mathrm{ATPase}$ (see reference 10). If such a relationship exits, amiloride, which inhibits electrogenic $\mathrm{Na}$ absorption, should inhibit $\mathrm{K}$ secretion. Studies that have examined this relationship have not always observed such inhibition of $\mathrm{K}$ secretion by amiloride. In general, experiments performed under open circuit conditions have shown an inhibition of $\mathrm{K}$ secretion (simultaneous with inhibition of $\mathrm{Na}$ absorption), e.g. in rabbit cortical collecting tubule $(28,29)$, whereas those performed under short circuit conditions have not, e.g. in rabbit colon $(7,8,30)$. It is likely that the inhibition of $\mathrm{K}$ secretion by amiloride under open circuit conditions is due to a decrease in potential-dependent $\mathrm{K}$ secretion and not to an effect on active $\mathrm{K}$ secretion. In distal colon of $\mathrm{Na}$-depleted rats amiloride-sensitive $\mathrm{Na}$ absorption is the predominant $\mathrm{Na}$ transport process $(2,6)$, but in Ringer's solution, under short circuit conditions, amiloride has not inhibited active $K$ secretion (2). In contrast, in the absence of serosal $\mathrm{Na}$ in aldosterone animals mucosal amiloride resulted in a prompt reduction in both the $I_{\mathrm{sc}}$ and $J_{\mathrm{sm}}^{\mathrm{K}}$ (Fig. 4). Since a close coupling between $\mathrm{Na}$ absorption and $\mathrm{K}$ secretion is only observed (Fig. 4) when the basolateral $\mathrm{Na}-\mathrm{K}-2 \mathrm{Cl}$ cotransport system is inhibited, we interpret these results to indicate that the major fraction of $\mathrm{K}$ secretion is derived from $\mathrm{Na}-\mathrm{K}-2 \mathrm{Cl}$ cotransport which is not linked to $\mathrm{Na}$ absorption. These results also suggest that a portion of $\mathrm{K}$ secretion occurs in $\mathrm{Na}$ absorbing cells.

Relation between $K$ secretion and $K$ absorption. Alteration in any of the processes by which $K$ enters the cell, namely 
inhibition of basolateral $\mathrm{Na}, \mathrm{K}$-pump or $\mathrm{Na}-\mathrm{K}-2 \mathrm{Cl}$ cotransport process, resulted in a marked stimulation of $J_{\mathrm{ms}}^{\mathrm{K}}$ in the aldosterone animal (Tables I and II; Figs. 1, 2, and 4). These results suggest that a subpopulation of colonocytes might contain both the $\mathrm{K}$ absorptive and $\mathrm{K}$ secretory processes because there was significant correlation $(P<0.02)$ between inhibition of $J_{\mathrm{sm}}^{\mathrm{K}}$ and augmentation of $J_{\mathrm{ms}}^{\mathrm{K}}$ (Fig. 5). In the absence of more definitive information we would speculate that these two transport processes may also reside in separate cells.

The mechanism responsible for this coupling between bidirectional transepithelial $\mathrm{K}$ movement is unknown but a reasonable explanation could be advanced based on our results and the arguments presented previously by Wills and Biagi (31). In rabbit descending colon $(31,32)$ and in rabbit (33) and Necturus (34) gallbladders intracellular K activity is normally above its electrochemical equilibrium and within the range of 73-86 mM. This would provide the gradient for conductive $\mathrm{K}$ exit across the apical membrane. Indeed, in guinea pig distal colon, high $\mathrm{K}$ concentration $(105.4 \mathrm{mM})$ in the mucosal bath abolished the $I_{\text {sc }}$, and therefore, $\mathrm{K}$ secretion (21). As a result, it is reasonable to suggest that the following speculation may explain the relationship between the decrease in $J_{\mathrm{sm}}^{\mathrm{K}}$ and the increase in $J_{\mathrm{ms}}^{\mathrm{K}}$. A decrease in uptake of $\mathrm{K}$ across the basolateral membrane most likely decreases intracellular $\mathrm{K}$ activity and thereby reduces the potential across the apical membrane. The resulting decrease in apical membrane $\mathrm{K}$ conductance would lead to a decrease in apical membrane $\mathrm{K}$ recycling and thus an increase in $J_{\mathrm{ms}}^{\mathrm{K}}$. It is most likely that the increase in $J_{\mathrm{ms}}^{\mathrm{K}}$ occurs in aldosterone but not in normal animals since there is a three-fold increase in $J_{\max }$ without a change in $\mathrm{Km}$ of the active $\mathrm{K}$ absorptive process in aldosterone compared to nor-

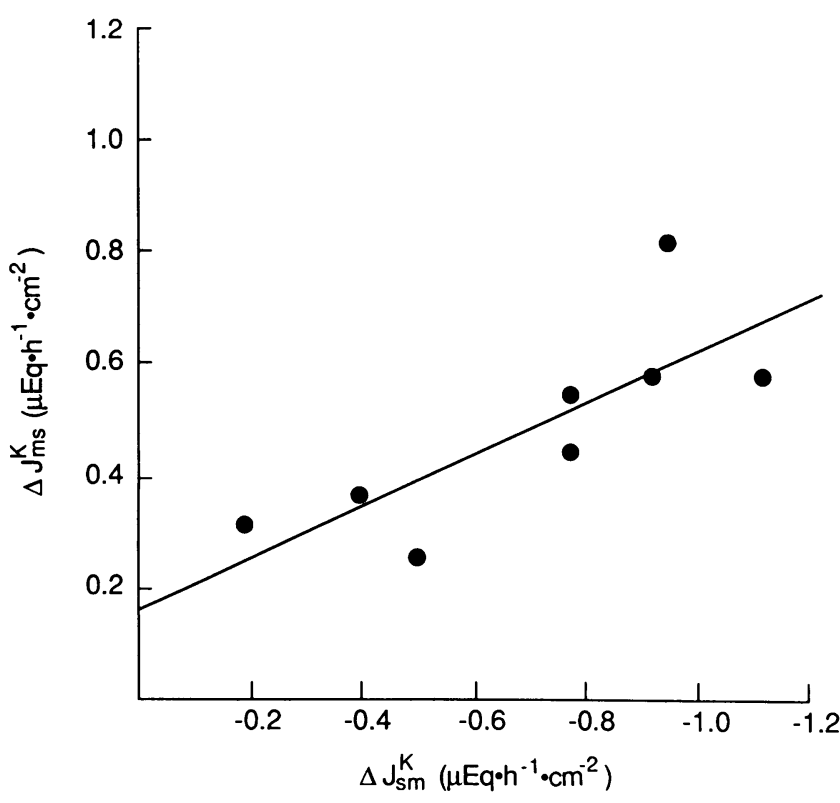

Figure 5. Relationship between inhibition of serosal-to-mucosal $\left(J_{\mathrm{sm}}^{\mathrm{K}}\right)$ and stimulation of mucosal-to-serosal $\left(J_{\mathrm{ms}}^{\mathrm{K}}\right) \mathrm{K}$ movement after alteration of basolateral $\mathrm{K}$ uptake in the aldosterone group. $\Delta J_{\mathrm{ms}}^{\mathrm{K}}$ and $\Delta J_{\mathrm{sm}}^{\mathrm{K}}$ represent the difference between control values and those measured after inhibition of basolateral $\mathrm{K}$ uptake (see Tables I [section B] and III [section B], and Figs. 1, 2, and 4). A line was fitted (by least-square analysis) to the data points: ordinate-intercept $=0.16 \pm 0.11 \pm$, slope $=0.46 \pm 0.15 ; r=0.79(P<0.02)$. mal cells (35). However, the available data do not permit a definitive conclusion whether the $\mathrm{K}$ absorptive and secretory processes are only located in one cell type or are also present in different epithelial cells.

In summary, these findings demonstrate that in the normal rat distal colon, in which there is net $\mathrm{K}$ absorption in vitro under short-circuit conditions, the small $J_{\mathrm{sm}}^{\mathrm{K}}$ could be completely accounted for by an apical TEA- or Ba-sensitive $\mathrm{K}$ channel and a basolateral $\mathrm{Na}-\mathrm{K}-2 \mathrm{Cl}$ cotransport process. In the aldosterone animal, net $\mathrm{K}$ secretion is associated with the stimulation (or induction) of $\mathrm{K}$ channels in the apical membrane that are sensitive to both TEA and $\mathrm{Ba}$ and requires $\mathrm{Na}, \mathrm{K}-\mathrm{ATPase}$ and $\mathrm{Na}-\mathrm{K}-2 \mathrm{Cl}$ cotransport for $\mathrm{K}$ entry across the basolateral membrane.

\section{Acknowledgments}

This study was supported, in part, by U. S. Public Health Service research grant (DK-18777) from the National Institute of Diabetes, Digestive, and Kidney Diseases.

\section{References}

1. Edmonds, C. J. 1967. Transport of potassium by the colon of normal and sodium-depleted rats. J. Physiol. (Lond.). 193:603-617.

2. Foster, E. S., J. P. Hayslett, and H. J. Binder. 1984. Mechanism of active potassium absorption and secretion in the rat colon. Am. J. Physiol. 246:G611-G617.

3. Foster, E. S., W. J. Jones, J. P. Hayslett, and H. J. Binder. 1985. Role of aldosterone and dietary potassium in potassium adaptation in the distal colon of the rat. Gastroenterology. 88:41-46.

4. Sandle, G. I., E. S. Foster, S. A. Lewis, H. J. Binder, and J. P. Hayslett. 1985. The electrical basis for enhanced potassium secretion in rat distal colon during dietary potassium loading. Pfleugers Arch. Eur. J. Physiol. 403:433-439.

5. Kashgarian, M., C. R. Taylor, H. J. Binder, and J. P. Hayslett. 1980. Amplication of cell membrane surface in potassium adaptation. Lab. Invest. 42:581-588.

6. Foster, E. S., T. W. Zimmerman, J. P. Hayslett, and H. J. Binder. 1983. Corticosteroid alteration of active electrolyte transport in rat distal colon. Am. J. Physiol. 245:G668-G675.

7. Halm, D. R., and R. A. Frizzell. 1986. Active K transport across rabbit distal colon: relation to $\mathrm{Na}$ absorption and $\mathrm{Cl}$ secretion. Am. J. Physiol. 251:C252-C267.

8. Plass, H., A. Gridl, and K. Turnheim. 1986. Absorption and secretion of potassium by rabbit descending colon. Pfleugers Arch. Eur. J. Physiol. 406:509-519.

9. Dharmsathaphorn, K., K. G. Mandel, H. Masui, and J. A. McRoberts. 1985. Vasoactive intestinal polypeptide-induced choride secretion by a colonic epithelial cell line. Direct participation of a basolaterally localized $\mathrm{Na}^{+}, \mathrm{K}^{+}, \mathrm{Cl}^{-}$cotransport system. J. Clin. Invest. 75:462-471.

10. Schultz, S. G. 1981. Homocellular regulatory mechanisms in sodium-transporting epithelia: avoidance of extinction by "flushthrough". Am. J. Physiol. 241:F579-F590.

11. Gunter-Smith, P. J., E. Grasset, and S. G. Schultz. 1982. Sodium-coupled amino acid and sugar transport by Necturus small intestine. An equivalent electrical circuit analysis of a rheogenic co-transport system. J. Membr. Biol. 66:25-39.

12. Martin, R. S., W. J. Jones, and J. P. Hayslett. 1983. Animal model to study the effect of adrenal hormones on epithelial function. Kidney Int. 24:386-391.

13. Halevy, J., M. E. Budinger, J. P. Hayslett, and H. J. Binder. 1986. Role of aldosterone in the regulation of sodium and chloride transport in the distal colon of sodium-depleted rats. Gastroenterology. 91:1227-1233. 
14. Foster, E. S., G. I. Sandle, J. P. Hayslett, and H. J. Binder. 1986. Dietary potassium modulates active potassium absorption and secretion in rat distal colon. Am. J. Physiol. 251:G619-G626.

15. O'Grady, S. M., H. C. Palfrey, and M. Field. 1987. Characteristics and functions of Na-K-Cl cotransport in epithelial tissues. Am. J. Physiol. 253:C177-C192.

16. McCabe, R., H. J. Cooke, and L. P. Sullivan. 1982. Potassium transport by rabbit descending colon. Am. J. Physiol. 242:C81-C86.

17. Wills, N. K., and A. Zweifach. 1987. Recent advances in the characterization of epithelial ionic channels. Biochim. Biophys. Acta. 906:1-31.

18. O'Neil, R. G., and S. C. Sansom. 1984. Electrophysiological properties of cellular and paracellular conductive pathways of the rabbit cortical collecting tubule. J. Membr. Biol. 82:281-295.

19. Wills, N. K., W. Zeiske, and W. Van Driessche. 1982. Noise analysis reveals $\mathrm{K}+$ channel conductance fluctuations in the apical membrane of rabbit colon. J. Membr. Biol. 69:187-197.

20. McCabe, R. D., P. L. Smith, and L. P. Sullivan. 1984. Ion transport by rabbit descending colon: mechanisms of transepithelial potassium transport. Am. J. Physiol. 246:G594-G602.

21. Ishida, H., and Y. Suzuki. 1987. Potassium secretion in the guinea pig distal colon. Jpn. J. Physiol. 37:33-48.

22. Demarest, J. R., and A. L. Finn. 1987. Characterization of the basolateral membrane conductance of Necturus urinary bladder. $J$. Gen. Physiol. 89:541-562.

23. Kawahara, K., M. Hunter, and G. Giebisch. 1987. Potassium channels in Necturus proximal tubule. Am. J. Physiol. 253:F488F494.

24. Gregor, R. 1985. Ion transport mechanisms in thick ascending limb of Henle's loop of mammalian nephron. Physiol. Rev. 65:760797.

25. Sachs, J. R. 1977. Kinetics of the inhibition of the Na-K pump by external sodium. J. Physiol. (Lond.). 262:449-470.

26. Demarest, J. R., and A. L. Finn. 1987. Interaction between the basolateral $\mathrm{K}+$ and apical $\mathrm{Na}+$ conductances in Necturus urinary bladder. J. Gen. Physiol. 89:563-580.
27. Kinne, R., J. A. Hannafin, and B. Konig. 1985. Role of NaCl$\mathrm{KCl}$ cotransport system in active chloride absorption and secretion. Ann. NY Acad. Sci. 456:198-206.

28. Stoner, L. C., M. B. Burg, and J. Orloff. 1974. Ion transport in cortical collecting tubule; effect of amiloride. Am. J. Physiol 227:453-459.

29. Wingo, C. S. 1985. Cortical collecting tubule potassium secretion: effect of amiloride, ouabain, and luminal sodium concentration. Kidney Int. 27:886-891.

30. Frizzell, R. A., M. J. Koch, and S. G. Schultz. 1976. Ion transport by rabbit colon. I. Active and passive components. J. Membr. Biol. 27:297-316.

31. Wills, N. K., and B. Biagi. 1982. Active potassium transport by rabbit descending colon epithelium. J. Membr. Biol. 64:195-203.

32. Wills, N. K., S. A. Lewis, and D. C. Eaton. 1979. Active and passive properties of rabbit descending colon: a microelectrode and nystatin study. J. Membr. Biol. 45:81-108.

33. Gunter-Smith, P. J., and S. G. Schultz. 1982. Potassium transport and intra-cellular potassium activities in rabbit gallbladder. $J$. Membr. Biol. 65:41-47.

34. Reuss, L. R., S. A. Weinman, and T. P. Grady. 1980. Intracellular $\mathrm{K}+$ activity and its relation to basolateral membrane ion transport in Necturus gallbladder epithelium. J. Gen. Physiol. 76:33-52.

35. Binder, H. J., and J. H. Sweiry. 1988. Effects of dietary-sodium depletion on potassium transport in rat distal colon in vitro: kinetics of $\mathrm{K}$ absorption and the regulatory role of $\mathrm{K}$ secretory channels. J. Physiol. (Lond.). 396:34P. (Abstr.).

36. O’Grady, S. M., H. C. Palfrey, and M. Field. 1987. Na-K-2Cl cotransport in winter flounder intestine and bovine kidney outer medulla: $\left[{ }^{3} \mathrm{H}\right]$ bumetanide binding and effects of furosemide analogues. $J$. Membr. Biol. 96:11-18.

37. Gregor, R., E. Schlatter, and F. Lang. 1983. Evidence for electroneutral sodium chloride cotransport in the cortical thick ascending limb of Henle's loop of rabbit kidney. Pfleugers Arch. Eur. J. Physiol. 396:308-314. 